\title{
Proceeding
}

Supplementary Issue: Spring Conferences of Sports Science. Costa Blanca Sports Science Week, 26-28 April 2018. Calpe. Alicante, Spain

\section{Differences between students according to physical activity and their motivation, basic psychological needs and responsibility}

\author{
DAVID MANZANO-SÁNCHEZ $\triangle$, ALFONSO VALERO-VALENZUELA \\ Department of Physical Activity and Sport, University of Murcia, Murcia, Spain
}

\begin{abstract}
The objective of this research was to analyse the differences in physical activity, basic psychological needs, motivation and responsibility in students. A sample of 109 participants was chosen $(M=16.29, S D=.95)$, who were given a questionnaire to assess their satisfaction of basic psychological needs (PNSE), motivation (BREQ-2) and responsibility (PSRQ), together with a physical activity measurement instrument. The participants were grouped for analysis according to the percentile of physical activity in "low active", "some active" or "very active". The results indicated no differences according to gender in physical activity. On the one hand the very active group had higher values of physical activity with respect to the rest of the groups, and these values were higher at weekends compared to the rest of the week, whereas, low and some active groups obtained higher values during the week. In addition, the very active group presented higher values in intrinsic motivation, autonomy, competence and lower in amotivation. We concluded the need to promote physical activity especially at weekends, encouraging the satisfaction of basic psychological needs to obtain higher levels of motivation. Key words: HEALTHY HABITS, COMPETENCE, PHYSICAL ACTIVITY, AUTONOMY, ADOLESCENTS.
\end{abstract}

\section{Cite this article as:}

Manzano-Sánchez, D., \& Valero-Valenzuela, A. (2018). Differences between students according to physical activity and their motivation, basic psychological needs and responsibility. Journal of Human Sport and Exercise, 13(2proc), S221-S230. doi:https://doi.org/10.14198//ihse.2018.13.Proc2.06

Corresponding author. Department of Physical Activity and Sport, University of Murcia, post code 30007. Murcia, Spain. http://orcid.org/0000-0003-2155-4515

E-mail: david.manzano@um.es

Supplementary Issue: Spring Conferences of Sports Science. Costa Blanca Sports Science Week, 26-28 April 2018. Calpe. Alicante, Spain.

JOURNAL OF HUMAN SPORT \& EXERCISE ISSN 1988-5202

(c) Faculty of Education. University of Alicante

doi: 10.14198/jhse.2018.13.Proc2.06 


\section{INTRODUCTION}

Nowadays, the importance of physical activity to be in an optimal state of health, seems undeniable but, although people are increasingly aware of its importance (Rivero, 2010), in recent years, the general population and especially the younger generation have not shown signs of an increase in the practice of physical activity (Tercedor et al., 2007), which must consist of a minimum of 60 minutes a day of moderatevigorous aerobic physical activity and / or 10.000 daily steps, as well as 3 days per week of sports activities for the locomotor system (OMS, 2010).

Although the parameters that measure physical activity are volume, frequency, density and intensity (Bompa, 2003), it seems that the most relevant in terms of improving health and body composition is intensity (Heydari, Frund and Boutcher, 2016). Several studies have identified with various protocols that intensity has more importance to improve of cardiovascular health and anthropometric parameters in adults (Molina, Cifuentes, Martínez, Mancilla and Díaz, 2016) and in young adolescents (Heydari et al., 2016).

According to the weekly schedule, we can find different results depending on the segment analysed. For instance, Beltrán et al. (2017) studied the segments of morning, lunch, afternoon, night and early morning during the week and at weekends, without any significant differences in general terms. While, Abarca et al. (2010) found statistically significant differences according to the schedule, with greater physical activity on school days for boys and girls. The same results were obtained by Nilsson et al. (2009) and Nader et al. (2008) also finding greater physical activity levels during the week for both genders, especially during school time.

Referring to gender, it seems that there are differences between boys and girls, with higher values of moderate and vigorous physical activity (MVPA) in boys regardless of whether they are measured during the week or at weekends (Aibar et al., 2014; Beltrán et al., 2017) whereas, the light or very light activity values higher in girls without differences between weekends and during the week (Molinero et al., 2010). Bailey et al. (2012) identified that boys perform more MVPA during school time but found no differences in out ofschool time.

Therefore, it should be noted that there are many reasons people do not do physical activity (Rodríguez et al., 2009). The reasons most cited by young people are: negative experiences in school practice, lack of support and the lack of role models (Allender et al., 2006). Faced with this problem, this highlights the great interest in finding the reasons why people tend to adopt more or less active behaviour, and therein the theory of achievement goals (Duda and Nicholls, 1992), together with the theory of self-determination (Deci and Ryan, 1985), these being the most studied within the sport context and physical education.

The studies agree that people who perform more physical activity have a greater intrinsic motivation, and this increases especially in vigorous activity (Cervelló et al., 2014; Folgar et al., 2014; Moreno et al., 2013), generating greater general satisfaction task-oriented experiences and intrinsic motivation (Manzano and Valero, 2014). It should be noted that there are differences according to gender, generally boys have a greater intrinsic and extrinsic motivation compared to girls in physical activities practiced (Alonso et al.; 2012; Amado et al., 2014; Folgar et al., 2014).

One of the most important determinants linked to the self-determination theory are the basic psychological needs, especially the autonomy need satisfaction (Deci and Ryan, 1985) that corresponds to the essential element of self-determination, being the major determinant for the beginning and maintenance in the practice 
of physical activity (Deci and Ryan, 1987). Thus, it has been observed that young people who perceive a high degree of autonomy of their partners or coaches, have a greater motivation towards practicing physical activity (Reinboth et al., 2004). People who are more active, have more continuity with sports and have greater satisfaction in the three basic psychological needs (García et al., 2011).

Furthermore, positive development in young people has created great importance in education and psychology (Lerner et al., 2003), seeing a clear relationship between physical activity and psychological and social development (Wright and $\mathrm{Li}, 2009$ ). In this sense, studies indicate that the most active people will experience a greater level of responsibility (Gómez-Mármol et al., 2017), especially when they are accompanied by an increase in the possibility of choosing autonomously and greater intrinsic motivation (Belando et al., 2012). Therefore, in Physical Education, physical activity should be promoted in a fun, simple and effective way to develop this type of Responsibility (Martinek et al., 2009).

Accordingly, this study aims to classify young school children according to their level of physical activity to discover the possible differences in physical activity between week and weekend and gender, and also to see if there are differences in the satisfaction of basic psychological needs, motivation and personal and social responsibility.

It is hypothesised that the most active students will have the highest satisfaction of their basic psychological needs, greater intrinsic motivation, as well as higher levels of personal and social responsibility, both during the week and at weekends and also have higher values of physical activity in general compared to girls.

\section{MATERIALS AND METHODS}

\section{Participants}

An intentional sampling was made according to the possibility of access and control of the especific sample, finally choosing an educational centre of Secondary School. A total of 132 participants were chosen, of which only 109 met the inclusion and exclusion criteria; who completely answered all the questionnaire questions; used pedometers or accelerometers a minimum of 3 days a week and 1 weekend day; performed with the pedometer on the days tested with a minimum of 750 daily steps and to have a record of minimum 600 minutes each day with the accelerometers.

The final sample consisted of 109 participants (42 boys, 67 girls) between 16 and 18 years old ( $M=16.29$, $\mathrm{SD}=.95)$. To quantify objectively the physical activity levels, accelerometers were used with 24 students and pedometers with the rest (85 participants). The sociodemographic variables that were used to carry out the present study were gender and physical activity level. Informed written consent was also obtained from the students and their parents.

\section{Material and instruments}

Basic Psychological Needs. The Spanish version (Moreno-Murcia, González-Cutre, Chillón, \& Parra, 2008) of the Basic Psychological Needs in Exercise Scale (BPNES) was used. Participants answered on a Likerttype scale from 1 (Totally disagree) to 5 (Totally agree). The questionnaire started with the following sentence: "In my physical education classes....". Cronbach's $\alpha$ values were .80 for competence, $\alpha=.69$ for autonomy and $\alpha=.73$ for relatedness.

Motivation. Scale of Behavioural Regulation in Exercise Questionnaire-2 (BREQ-2) validated to the Spanish context by Moreno et al. (2007) and originally developed by Markland and Tobin (2004). Participants 
answered on a Likert-type scale from 1 (Totally disagree) to 6 (Totally agree), including a total of 19 items from five categories. The previous sentence used was: "I practice exercise ...". The internal consistency was values of $\alpha=.81$ for the intrinsic motivation, $\alpha=.81, \alpha=.82$ and $\alpha=.86$ for the three categories that composed extrinsic motivation and $\alpha=.85$ for the amotivation.

Responsibility. The Spanish validated version (Escartí, Gutiérrez \& Pascual, 2011) of the Personal and Social Responsibility Questionnaire (PSRQ) was used. Participants responded on a Likert-type scale from 1 (Totally disagree) to 6 (Totally agree). The instructions were presented at the beginning of the questionnaire along with the following statement: "It is normal to behave well at times and badly at other times. We are interested in finding out how you normally behave in physical education classes. There are no correct or incorrect answers. Please answer the following questions choosing the option which bests represents your behaviour". Cronbach's $\alpha$ for sub-scales were .74 and .85 respectively for personal and social responsibility.

Physical Activity: Pedometers are one of the most used objective instruments to measure physical activity, presenting high validity and reliability in the school context (Beets et al., 20005), but not all of them contribute data regarding the intensity of practice (Hernández et al. al., 2010). For the present study they used a total of 85 pedometers of the Omron brand; Walking Style One 2.1, which reflects the number of steps and distance walked, but also includes an intensity factor such as the steps taken in the aerobic activity type (activity at least 10 minutes followed by a minimum of 60 steps per minute as intensity indicator), with a 7 day memory.

On the other hand, accelerometry leads the gold standard to quantify this intensity more precisely, being in recent years the most used device in the school population (Rowlands, 2007). 24 GT3X Actigraph accelerometers of triple axis were used, giving the results in counts that are the sum of the absolute values of the acceleration change (Torres et al., 2014). All the accelerometers were loaded and put in date and time, programmed to record from 7:30 a.m. to 23:30 p.m., with the frequency of data collection of $60 \mathrm{~Hz}$. For the analysis of time of activity measured by the accelerometer, the cut points proposed by Evenson et al. (2008) in children and young people and Moderate and Vigorous Activity (MVPA) was selected. MVPA is subsequently the sum of moderate and vigorous physical activity.

The children were informed of how to put it (pedometers on the hip and accelerometers on the wrist) and that none could get wet and in the case of doing water activities or swimming as extracurricular activities, participants should tell it to the teacher. A letter of presentation was also used, which was issued to the director of the centre, as well as to the Physical Education teacher with a consent form for the parents of the underage participants.

\section{Design and procedure}

A descriptive methodology with transversal design was used (Montero and León, 2007). The necessary authorisations were obtained from the Ethics Committee of the researchers' University and the schools' principals. Informed written consent was also obtained from the students and their parents. The questionnaires were administered in the presence of the principal investigator and the Physical Education teacher, in a calm environment for 20 minutes. We urged the participants to be honest and guaranteed their anonymity and assured them that their marks would not be affected.

Once the questionnaire was completed, pedometers and accelerometers were assigned randomly. Participants were reminded about the aspects to be taken into account about the pedometer or accelerometer wear time (7 days) and the delivery date. The phase began the first week of March, ending at the end of May. 


\section{Statistical analysis}

The Actilife 5.0 software was used. To analyse the students data, a period of 3 days during the week and 1 at weekend with 600 minutes of registration and counting the physical activity was required. For the pedometers, the final count of the steps was done as well as the steps taken in an active way.

The Cronbach's Alpha was analysed and the Kolmogorov-Smirnov and Shapiro-Wilk tests were performed for all the variables, showing a normal distribution, using parametric tests for independent samples. The data were recorded for the participants in "low active, some active or very active", according to percentages of the 33rd, 66th percentile or above both in the count of daily active steps (pedometers) and in moderate-vigorous physical activity (accelerometers). The statistical analysis and the evaluation of the results were carried out using the IBM SSPS 22.0 software.

\section{RESULTS}

\section{Physical activity}

Table 1 shows the total of active steps and the total time of moderate-vigorous physical activity that takes place during the week and at weekends measured by accelerometry. In addition, these data are compared according to the level of physical activity and gender.

Table 1. Physical activity during the week and at weekends measured with pedometers and accelerometers.

\begin{tabular}{|c|c|c|c|c|c|c|c|c|c|c|c|c|}
\hline & \multicolumn{2}{|c|}{ Low active } & \multicolumn{2}{|c|}{ Some Active } & \multicolumn{2}{|c|}{ Very Active } & \multicolumn{3}{|c|}{ Women } & \multicolumn{3}{|l|}{ Men } \\
\hline & Mean & SD & Mean & SD & Mean & SD & $p$ & Mean & SD & Mean & SD & $\bar{p}$ \\
\hline Active steps DW & 1507 & 372 & 3857 & 1194 & 6989 & 2531 & ** & 2240 & 2204 & 2757 & 1828 & - \\
\hline Active steps AW & 1185 & 470 & 2655 & 1612 & 9344 & 3209 & ** & 1387 & 2367 & 2086 & 2331 & - \\
\hline T MVPA WD & 116,8 & 28,68 & 169 & 19,36 & 224,5 & 49,19 & ** & 163,5 & 40 & 156,4 & 58 & - \\
\hline T MVPA WE & 85,3 & 43,87 & 105,2 & 29,28 & 250,4 & 156,89 & ** & 142,3 & 56 & 115,6 & 111 & - \\
\hline
\end{tabular}

In Table 1, we can see that there are statistically significant differences in all the variables in $p<.01$ between the very active, some active and low active groups. It is observed that the participants of low active and some active groups, perform most of the activity during the week. However, the very active group performs it at weekends. According to gender, no statistically significant differences were found between boys and girls.

\section{Basic Psychological Needs, Motivation and Responsibility}

Table 2 shows the variables of basic psychological needs, motivation and responsibility, comparing them to the current physical activity level.

The analysis of the results shows significant differences among the students of the very active group with respect to the some active and low active groups in competence $(\mathrm{M}=3.90, \mathrm{SD}=.55, \mathrm{M}=3.40, \mathrm{SD}=.62, \mathrm{M}$ $=3.13, \mathrm{SD}=.57)$, autonomy $(\mathrm{M}=3.44, \mathrm{SD}=.67, \mathrm{M}=3.21, \mathrm{SD}=.83, \mathrm{M}=2.83, \mathrm{SD}=.88)$, intrinsic motivation $(\mathrm{M}=3.84, \mathrm{SD}=.97 ; \mathrm{M}=3.84, \mathrm{SD}=1.07, \mathrm{M}=3.16, \mathrm{SD}=.92)$ as well as in amotivation $(\mathrm{M}=1.75, \mathrm{SD}=.99$, $M=2.15, S D=1.04, M=2.35, S D=.88)$. No statistically significant differences in the relatedness or personal and social responsibility were found. 
Table 2. Physical activity and psychological variables

\begin{tabular}{|c|c|c|c|c|c|c|c|}
\hline & \multicolumn{2}{|c|}{ Low Active } & \multicolumn{2}{|c|}{ Some Active } & \multicolumn{2}{|c|}{ Very Active } & \\
\hline & Mean & SD & Mean & SD & Mean & SD & $P$ \\
\hline Competence & 3.13 & .57 & 3.40 & .62 & 3.90 & .55 & * \\
\hline Relatedness & 3.77 & .94 & 3.76 & .90 & 4.11 & .78 & \\
\hline Autonomy & 2.83 & .88 & 3.21 & .83 & 3.44 & .67 & * \\
\hline Intrinsic Motivation & 3.16 & .92 & 3.35 & 1.07 & 3.84 & .97 & * \\
\hline Extrinsic Motivation & 3.29 & .85 & 3.34 & .68 & 3.27 & .79 & - \\
\hline Amotivation & 2.35 & .88 & 2.15 & 1.04 & 1.75 & .99 & * \\
\hline Social Responsibility & 3.90 & .88 & 4.10 & .80 & 4.17 & .62 & - \\
\hline Personal Responsibility & 3.66 & .72 & 3.73 & .77 & 3.85 & .50 & - \\
\hline
\end{tabular}

\section{DISCUSSION}

The objective of this study was firstly to classify young school children according to their physical activity level and, on the other hand, to discover if there are differences depending on the day of the week they do their exercise and their gender, as well as the satisfaction of the basic psychological needs, motivation and personal and social responsibility.

With regard to physical activity during the week and at weekends, it should be noted that although the participants of very active group always performed more physical activity, we have seen that they have higher values in MVPA or active steps at weekends, and on the other hand, the less active groups show higher values during the week. Different studies have agreed adolescents and children have higher physical activity levels on weekdays (Abarca et al 2010, Nailsson et al 2009, Nader et al 2008). In contrast, in the present study we found that the participants of the very active group, have a different tendency, their physical activity levels being higher at weekends, compared to the low and some active participants with higher values during the week.

Meanwhile, based on gender, the results obtained in this study contrast with those of Beltrán et al. (2017) who found that boys had more moderate and vigorous physical activity in practically all measurements, as well as Aibar et al. (2014) both during the week and at weekends. In contrast, the data from this study are in line, at least in part, with those of Bailey et al. (2012) where there are no differences according to gender in physical activity done in out of-school time, neither during the week nor at weekends, and only during class time.

The analysis of the satisfaction of basic psychological needs reflected statistically significant differences in two of them, specifically in the autonomy and competence. In terms of relatedness, a favourable trend was observed in the very active group but not in a statistically significant way. This is corroborated by many studies that indicate that the most intrinsically motivated participants have greater satisfaction in their three basic psychological needs in physical education and in the sport context (Almagro et al., 2011; Méndez et al., 2013) and so, the most active people have greater satisfaction in the three basic psychological needs (García et al., 2011).

Regarding motivation, the results indicate that the students who were considered within the very active group, showed much higher values of intrinsic motivation with respect to the low and some active groups and less amotivation, corroborating other studies like Moreno et al. (2013) and Cervelló et al. (2014). No statistical 
significant differences were found in the extrinsic motivation. This data is in line with the study by Folgar et al. (2014) with young school children who do physical activity in both federated and non-federated contexts.

Finally, regarding the levels of responsibility, in this study, no significant results were reflected among the participants of the very active group and their levels of personal and social responsibility. In contrast, Belando et al. (2012) and Gómez-Mármol et al. (2017) indicate that those people who are more active, have a higher level of personal and social responsibility as long as it is accompanied by an increase in the possibility of choosing autonomously and with higher intrinsic motivation.

The main limitation of this study has been the reduced sample size, especially in terms of accelerometry, since many of the participants had to be excluded because they did not meet the inclusion criteria. Furthermore, the possibility of comparing pedometers and accelerometers in the same group would make the data corroborate in a more valid and reliable way than between different groups.

\section{CONCLUSIONS}

In conclusion, no differences in physical activity were found according to gender. The very active group had higher physical activity values than the rest of the groups, and these values were higher at weekends. In contrast, the less active groups obtained higher values during the week. In addition, the very active group presented higher values in intrinsic motivation, autonomy, competence and lower in amotivation. Physical activity does not seem to relate to responsibility in a significant way, although the trend was positive, which encourage more studies to be done in this line.

Future studies should consider the differences in physical activity between during the week and weekends, in order to promote health in young people, since low and some active participants had lower levels of physical activity at weekends compared to during the week. This could be because they do most of their physical activity during Physical Education classes and extracurricular activities. In contrast, the very active participants, as well as performing these activities, they concentrate most of the physical activity time during the weekend.

\section{REFERENCES}

Abarca, A., Zaragoza, J., Generelo, E., and Clemente, J. A. (2010). Comportamientos sedentarios y patrones de actividad física en adolescentes. RIMCAFD, 10(39), 410-427.

Aibar, A., Bois, J., Zaragoza, J., Generelo, E. Paillard, T. and Fairclough, S. (2014). Weekday and weekend physical activity patterns of French and Spanish adolescents. Eur. J. Sport. Sci. Eur., 14(5), 500-509. https://doi.org/10.1080/17461391.2013.829127

Allender, S., Cowburn, G. and Foster, C. (2006). Understanding participation in sport and physical activity among children and adults a review of qualitative studies. Health Educ. Res., 21(6), 826-835. https://doi.org/10.1093/her/cyl063

Almagro, B., Sáenz, P., González, D. and Moreno, J. A. (2011). Perceived motivational climate, psychological needs and intrinsic motivation as predictors of sport commitment in adolescent athletes. RICYDE. 7(25), 250-265.

Alonso, D., Marcos, F., Oliva, D., Ponce, I. and Chamorro, J. (2012). ¿Es compatible el deporte en edad escolar con otros roles sociales? Un estudio a través de la Teoría de la Autodeterminación. Retos, $21,50-52$. 
Amado, D., Sánchez, P., Leo, F., Sánchez, D. and García, T., (2014). Diferencias de género en la motivación y percepción de utilidad del deporte escolar. RIMCAFD, 14(56), 651-664.

Beets, M., Patton, M. and Edwards, S. (2005). The accuracy of pedomter steps in time during walking in children. MSSE, 37, 513-520.

Belando, N., Morell, R. and Moreno, J. A. (2012). Mejora personal y social a través de la promoción de la responsabilidad en la actividad físico-deportiva. RICYDE, 8(29), 202-222.

Beltrán Carrillo, V. J., Sierra, A. C., Jiménez Loais, A., González-Cutre, D., Martínez Galindo, C. and Cervelló, E. (2017). Diferencias según género en el tiempo empleado por adolescentes en actividad sedentaria y actividad física en diferentes segmentos horarios del día. Retos, 31, 3-7.

Beltrán, J., Devís, J. and Peiró-Velert, C. (2012) Actividad física y sedentarismo en adolescentes de la comunidad valenciana. RIMCAFD, 12(45), 123-137.

Bompa, T. O. (2003). Periodización. Teoría y metodología del entrenamiento. Editorial Hispano Europea.

Cervelló, E., Peruyero, F., Montero, C., González, D., Beltrán, V. y Moreno, J.A. (2014). Ejercicio, bienestar psicológico, calidad de sueño y motivación situacional en estudiantes de educación física. CPD 14(3), 31-38. https://doi.org/10.4321/S1578-84232014000300004

Deci, E. and Ryan, R. (1985). Intrinsic motivation and self-determination in human behavior. Springer Science y Business Media: New York. https://doi.org/10.1007/978-1-4899-2271-7

Deci, E. and Ryan, R. (1987). The support of autonomy and the control of behavior. JPSP, 53, 1024 1037. https://doi.org/10.1037/0022-3514.53.6.1024

Duda, J. and Nicholls, J. (1992). Dimensions of achievement motivation in schoolwork and sport. J. Educ. Psychol., 84, 1-10. https://doi.org/10.1037/0022-0663.84.3.290

Duda, J. (2007). Propiedades psicométricas de la escala de motivación deportiva en deportistas españoles. Rev. Mex. Psycol., 24(2), 197-207.

Escartí, A., Gutiérrez, M., and Pascual, C. (2011). Propiedades psicométricas de la versión española del Cuestionario de Responsabilidad Personal y Social en contextos de educación física. RPD, 20(1), 119-130.

Evenson, K., Catellier, D., Gill, K. Ondrak, K. and McMurray, R. (2008) Calibration of two objective measures of physical activity for children. J. Sports Sci., 26(14), 1557-1565. https://doi.org/10.1080/02640410802334196

Folgar, M., Boubeta, A. and Cristobal, R. (2014). Motivaciones para la práctica deportiva en escolares federados y no federados. Retos, 25, 80-84.

García, T., Miguel, P., Marcos, F., Oliva, D. and Alonso, D (2011). Incidencia de la Teoría de Autodeterminación sobre la persistencia deportiva. Incidence of Self-Determination Theory of sport persistence). RICYDE, 7(25), 266-276.

Gómez-Mármol, A., Sánchez-Alcaraz, B.J., De la Cruz, E., Valero, A. and González-Víllora, S. (2017). Personal and Social Responsibility Development through Sport Participation in Youth Scholars. JPES, 17(2), 775-782.

Hernández L., Ferrando J.A., Quilez J., Aragonés M. and Terreros J. (2010). Análisis de la actividad física en escolares del medio urbano. Investigación en Ciencias del Deporte. Madrid: Consejo Superior de Deportes.

Heydari, M., Freund, J., \& Boutcher, S. H. (2016). Efecto de Ejercicio Intermitente de Alta Intensidad sobre la Composición Corporal de Varones Jóvenes con Sobrepeso. Rev. Edu. Fis., 143, 31-42.

Hughes, T. and Ganguli, M. (2010). Factores de riesgo de demencia en la vejez modificables en las etapas medias de la vida. Rev Neurol, 51(5), 259-262.

Infante, G. y Goñi, E. (2006). Actividad físico-deportiva y autoconcepto físico en la edad adulta. J. Psychodidactics, 14(1), 49-62. 
Lee, O. and Martinek, T. (2009). Navigating two cultures: An investigation of cultures of responsibilitybased physical activity program and school. Res. Q. Exerc. Sport., 80(2), 230-240. https://doi.org/10.1080/02701367.2009.10599557

Lerner, R. M., Dowling, E. and Anderson, P. M. (2003). Positive youth development: Thriving as the basis of personhood and civil society. Appl. Dev. Sci, 7(3), 172-180. https://doi.org/10.1207/S1532480XADS0703_8

Manzano, D. and Valero, A. (2013). Análisis del perfil motivacional de diversos grupos de atletas y su repercusión en el nivel de satisfacción deportiva. Sport TK, 2(2), 9-19. https://doi.org/10.6018/194571

Markland, D. and Tobin, V. (2004). A modification to Behavioural Regulation in Exercise Questionnaire to include an assessment of demotivation. J. Sport and Exerc. Psychol., 26, 191-196. https://doi.org/10.1123/jsep.26.2.191

Martinek, T., Ruiz, L. y García, V. (2009). Deporte, responsabilidad y grupos marginales: El papel de la investigación centrada en la Comunidad. En J. A. Moreno y D. González-Cutre, (Eds), Deporte, intervención y transformación social (pp. 307-334). Rio de Janeiro: Shape.

Martínez, J., Rodríguez, M. and Jiménez-Beatty, J. (2010). Influencia de la educación física escolar en la práctica de actividad física en la vejez. Motriz. Rev. Ed. Fis., 13, 71-86.

Méndez, A., Fernández, J. and Cecchini, J. A. (2013). Papel importante del alumnado, necesidades psicológicas básicas, regulaciones motivacionales y autoconcepto físico en educación física. CPD, 13(1), 71-82. https://doi.org/10.4321/S1578-84232013000100008

Molina, C., Cifuentes, G., Martínez, C., Mancilla, R., \& Díaz, E. (2016). Disminución de la grasa corporal mediante ejercicio físico intermitente de alta intensidad y consejería nutricional en sujetos con sobrepeso u obesidad. Rev. Med. Chile, 144(10), 1254-1259. https://doi.org/10.4067/S003498872016001000003

Molinero, O., Martínez, R., Garatachea, N. and Márquez, S. (2010). Pautas de actividad física de adolescentes españolas: diferencias mediadas por la participación deportiva y el día de la semana. RPD, 19(1). 103-116.

Moreno, J. A., Marzo, J. C., Martínez-Galindo, C. and Marín, L. C. (2011). Validación de la Escala de "Satisfacción de las Necesidades Psicológicas Básicas" y del Cuestionario de la "Regulación Conductual en el Deporte" al contexto español. RICYDE, 7(26), 355-369.

Moreno, J. A., Torregrosa, Y. and Marín, L. (2013). Relación del feed-back positivo y el miedo a fallar sobre la motivación intrínseca/Relatioship between positive feedback and the fear of failure of intrinsic motivation. REOP, 24(2), 8-23. https://doi.org/10.5944/reop.vol.24.num.2.2013.11256

Moreno, J., Cervello, E. and Martínez, A. (2007). Measuring self-determination motivation in a physical fitness setting: validation of the Behavioural Regulation in Exercise Questionnaire-2 (BREQ-2) in a Spanish sample. J. Sports. Med. Phys. Fitness, 47(3), 366-378.

Nader, P., Bradley, R., Houts, R., McRitchie, S. and O'Brien, M. (2008). Moderate-to-vigorous physical activity from ages 9 to 15 years. JAMA, 300(3), 295-305. https://doi.org/10.1001/jama.300.3.295

Nilsson, A., Anderssen, S., Anderssen, L., Froberg, K., Riddoch, C., Sardinha, L. and Ekelund (2009). Between and within day variability in phyisical activity and inactivity in 9 and 15 years old European children. Scand J Med Sci Sports, 19(1), 10-18. https://doi.org/10.1111/j.1600-0838.2007.00762.x

Organización Mundial de la Salud (OMS, 2010). Recomendaciones mundiales sobre actividad física para la salud. Ginebra (Suiza): Organización Mundial de la Salud.

Piéron, M., de la Cruz, E. and Ruíz, F. (2009). Frecuencia, duración, intensidad y niveles de actividad física en adultos durante el tiempo libre. En F. Ruiz, M.E. García y M. Piéron (coord.). Actividad física y estilos de vida saludables. Análisis de los determinantes de práctica en adultos. Almeria: Wanceulen Editorial Deportiva. 
Reinboth, M., Duda, J. and Ntoumanis, N. (2004). Dimensions of coaching behavior, need satisfaction, and the psychological and physical welfare of young athletes. Motiv. Emot., 28(3), 297-313. https://doi.org/10.1023/B:MOEM.0000040156.81924.b8

Rivero, A. (2010). Los valores del regeneracionismo en la educación física española (1898-1936). REEFD, 385(11), 13-24.

Rockafellow, B. and Saules, K. (2006). Substance use by college students: the role of intrinsic versus extrinsic motivation for athletic involvement. Psychol. Addict. Behav., 20(3), 279-287. https://doi.org/10.1037/0893-164X.20.3.279

Rodríguez, G., Boned, C. and Garrido, M. (2009). Motivos y barreras para hacer ejercicio y practicar deportes en Madrid. Rev. Panam. Salud Pública, 26(3), 244-254. https://doi.org/10.1590/S102049892009000900009

Rowlands A. (2007) Accelerometer assessment of physical activity in children: An update. Pediatr Exerc Sci, 17,252-266. https://doi.org/10.1123/pes.19.3.252

Ruíz, F., García, M. and Piéron, M. (2009). Actividad física y estilos de vida saludables. Análisis de los determinantes de práctica en adultos. Almeria: Wanceulen Editorial Deportiva.

Sánchez, J. and Alonso, J. L.(2007). Análisis preliminar de las propiedades psicométricas de la versión española de la Escala de Necesidades Psicológicas Básicas en el Ejercicio Físico. RIPED, 2(2), 8392.

Sánchez, J. G. (2017). Volumen e intensidad de actividad física en el síndrome metabólico. Revista Mexicana de Investigación en Cultura Física y Deporte, 5(7), 29-43.

Sigmund, E., Miklánková, L. and Frömel, K. (2007). Physical activity patterns of kindergarten children in comparison to teenagers and young adults. Eur. J. Public. Health., 7, 1-6. https://doi.org/10.1093/eurpub/ckm033

Tercedor, P., Martín, M., Chillón, P., Pérez-López, I. J., Ortega, F. B., Warnberg, J. and Delgado, M. (2007). Incremento del consumo de tabaco y disminución del nivel de práctica de actividad física en adolescentes españoles. Estudio AVENA. Nutr Hosp, 22(1), 89-94.

Torres, G., Calahorro, F., López, I. and Carnero, E. (2014), Impact of gender on levels of physical activity in Physical Education. SporTK, 3(1), 21-26.

Wilson, P, Rogers, W. Rodgers, W. and Wild, T. (2006). The psychological need satisfaction in exercise scale. J. Sport. Exerc. Psychol., 28(3), 231-251. https://doi.org/10.1123/jsep.28.3.231

Wright, P. and Li, W. (2009). Exploring the relevance of positive youth development in urban Physical $\begin{array}{llll}\text { Education. } & \text { Phys. Educ. Sport. Pedagog., } & \text { 14(3), }\end{array}$ https://doi.org/10.1080/17408980801974978

\section{(2) $\mathbb{Q \Theta \Theta}$}

This title is licensed under a Creative Commons Attribution-NonCommercial-NoDerivs 4.0 Unported License. 